\title{
Three European Sociologies of Religion: Beyond the Usual Agenda of the Discipline*
}

\author{
ZDENĚK R. NEŠPOR** \\ Institute of Sociology, Academy of Sciences of the Czech Republic, Prague
}

\begin{abstract}
The contemporary boom in the popularity of religion(s) and religiosity has led to new interest in their sociological study that has returned the sociology of religion to the heart of sociological research. In secular Europe alone, three new overviews of the discipline have appeared in 2006 and 2007, written by Grace Davie, I. Furseth and P. Repstad, and Z. R. Nešpor and D. Lužný, all of which attempt to go beyond the traditional agenda of the discipline. This review article summarises the various attitudes of the respective authors and provides a general overview of their books. However, rather than evaluating them it tries to use the three books as a starting point for thinking of the discipline itself. Primarily, the author examines whether there is one single sociology of religion or not and stresses the multiplicity of 'national' approaches with regard to the state of religion in respective societies. Beyond the attention usually paid to the European-American division, and Davie's 'hybrid cases' of British, Canadian, German and Eastern European versions of the sociology of religion, which are also discussed, the author outlines the particularities of the French and Scandinavian approaches. The article then concerns itself with the various theoretical and methodological issues surrounding the discipline and emphasises its 'post-paradigmatic' stage. While some sociologists are looking for new theories (Furseth and Repstad), others highlight the variety of methods which allow a deeper understanding of the multiplicity of facts and meanings (Davie, Nešpor and Lužný). Finally, the article discusses the specific position of religion(s) in post-communist countries and the ways in which it is studied.
\end{abstract}

Keywords: Sociology of religion, religion in Europe, post-communism, history of sociology

Sociologický časopis/Czech Sociological Review, 2008, Vol. 44, No. 3: 557-578

Few would question the decade-old statement of Peter L. Berger, that the contemporary world is 'as furiously religious as it has ever been, and in some places more so than ever' [Berger 1999: 2]. Even 'posthumous' supporters of the secu-

\footnotetext{
* This review article was written as part of project no. 403/08/0720 supported by the Grant Agency of the Czech Republic; the funding is gratefully acknowledged.

** Direct all correspondence to: Zdeněk R. Nešpor, Institute of Sociology, Academy of Sciences of the Czech Republic, Jilská 1, 11000 Prague 1, Czech Republic, e-mail: zdenek. nespor@soc.cas.cz.
}

(C) Sociologický ústav AV ČR, v.v.i., Praha 2008 
larisation thesis [e.g. Bruce 2002] must admit that the disappearance of religion from the public arena, international and domestic politics, and the current 'cultural wars', to mention just a few institutional spheres, is much slower and nonlinear than they previously thought it would be. And even if Western Europe is regarded as the place where this thesis still applies to a greater or lesser extent, as the exception that proves the rule of the world's desecularisation [Davie 2002], religious issues nonetheless play an important role here. Some authors maintain European 'religious boundaries', both external and internal, towards Islam and eastern Orthodoxy [Beckford 1994: 167; Nešpor 2007a], while others argue that post-Christian European secularism itself is a kind of religious attitude [Casanova 2004].

However, recognising the importance of religion(s) in the late modern world is one thing, its proper academic understanding and explanation is very much another. Although sociologists devoted a great deal of attention to religion in the founding years of their discipline, subsequently the subject was practically neglected by the European sociological mainstream. The British sociologist James A. Beckford explains the situation by the dominance of the secularisation thesis. As the great majority of sociologists were confident of a decline in the impact of religion in the public arena, they were inclined to ignore both religion itself and those studying this obscure subject [Beckford 1989, 2003]. The sociology of religion was thus 'insulated and isolated' from its parent discipline, undergoing its own development on the margins of sociology, deprived of a direct relationship to the ever-expanding field of sociological theory. In this regard an example is the British sociologist and prominent late modernist theorist, Anthony Giddens, whose writing on religion takes a somewhat old-fashioned view of the subject and pays no attention to the recent development of both religion and religiosity and to understanding these phenomena from the point of view of the sociology of religion and religious studies [Beck, Giddens and Lash 1994: 100; cf. Giddens 1991].

For many years, the situation differed in the United States, where there was no significant decline in religiosity in the second half of the 20th century, and where a number of various alternative religiosities witnessed significant growth. In the 'New World', which used to be regarded as the exception to the secularisation thesis, religion has been widely studied, and a 'new paradigm' - represented mainly by rational choice theory - has emerged in the sociology of religion [Warner 1993; cf. Young 1996]. Yet, even here mainstream sociology had widely abandoned the subject, at least until the 1980s [Vidich and Lyman 1985]. Granted, the sociology of religion and religious studies did occupy a position of sorts, but that position hovered on the margins of scholarly sociological discourse due to the simple fact that the highly skilled, international academic and business elites constituted the only other truly secularised milieu besides Western Europe [Berger 1999: 10-11]. Currently, the situation is changing rapidly, and sociologists are being forced to pay close attention to religion on both sides of the Atlantic, 
though admittedly American scholars are clearly better prepared; new monographs and textbooks on the subject of the sociology of religion appear more often in America than they do in Europe. ${ }^{1}$

Owing to the different social context, European sociologists of religion are somewhat disadvantaged. The historical prevalence of irreligious, post-religious, anti-religious, and especially anti-church attitudes in individual European societies have made research fund-raising difficult and have hindered the normal development of the discipline, including the education of new students, while today's shallow, 'fashionable' interest in the discipline implies a new danger: 'It would be a real shame, after all, if the field's response to trans-national religion and its role in world affairs simply shifted from one of disinterest to one of oversimplification' [Byrnes 2006: 302]. Fortunately, prominent European scholars of the sociology of religion have not been idle.

No fewer than three new introductions to the sociology of religion appeared in 2006 and 2007, and it is to these that this article is devoted. However, the aim is not just to review 'three books in one'. Instead, I would like to examine the ways in which the authors present their views in relation to their backgrounds, i.e. the 'national schools' in the sociology of religion, the differences in their theoretical perspectives and in the approaches they take to theory and the specific 'grand issues' they tackle in the field. The reader thus will not be asked to gauge 'which book is better'; instead, s/he will be invited to judge for him/herself the complex and burgeoning field of European sociology of religion. In fact, all the reviewed books are strongly trying to overcome the traditional agenda of the sociology of religion, and all of them are dependent on the national sociological milieus they emerged from.

\section{Three snapshots: Davie, Furseth and Repstad, and Nešpor and Lužný}

The alphabetical order of the authors in this title also reflects their respective impact on the international sociology of religion. Grace Davie is a prominent British sociologist who spent several years in France, Sweden and the United States, and is former chair of the research committee of the International Sociological Association. Consequently, virtually everything she writes is treated with the utmost respect. The two Norwegian scholars Inger Furseth and Pål Repstad are considerably less well known, but they produced a book in English which was subsequently published by a respected British publishing house, and which exerted considerable influence in the English-speaking circles of Scandinavian academia. In contrast, the two Czech authors Zdeněk R. Nešpor and Dušan Lužný have thus

\footnotetext{
${ }^{1}$ It is impossible to enumerate all the new publications on the subject, suffice it to say that many of them have been reviewed in this journal over the last few years; of the most widely used and frequently reprinted American textbooks, Bowie [2000], Hardgrove [1989], Johnstone [2004] and McGuire [2001] are particularly wort mentioning.
} 
far only contributed within their own national context (and to some extent also in Slovakia), since they have chosen to write in their own language. However, this probably does not automatically mean that the most influential book is the best written.

Davie's Sociology of Religion is clearly divided into two sections. The first five chapters deal with the various theoretical and methodological aspects of the discipline, and the second five chapters deal with the 'substantive issues' of presentday research - mainstream and minority religions, fundamentalism, globalisation and everyday religion (Davie 2007). In addition to the almost obligatory, short (and thus not always sufficient) review of the classics - Marx, Durkheim, Weber and Simmel - Davie devotes attention to the (non)existence of English translations of major publications and the diverse situation regarding 'national' sociological schools, the development of which she analyses with regard to the position of religion in respective societies. Quite surprisingly for an Englishspeaking author, she maintains that the sociology of religion cannot be reduced merely to its early French and German origins before the First World War and the Anglo-American mainstream since then, maintaining that there have been other less well-known schools, whose impact has been taken into account only recently. The authors cites the examples of French sociologie religieuse, Canadian, German, and Eastern European (i.e. communist) studies, to which can also be added the Scandinavian and Italian academic traditions [see, e.g., Cipriani 2000].

After this somewhat innovative prolegomena, Davie moves on to discuss the traditional distinction between the two sides of the Atlantic. In her opinion, European out-churching has led to the prevalence of the secularisation thesis, while American religiosity used to be explained as an exception, subsequently allowing the establishment of a 'new paradigm' in the study of the sociology of religion, namely, rational choice theory. However, Davie is unwilling to accept either particular viewpoint, and in fact seems more inclined to reject both perspectives. In agreement with the Israeli sociologist Shmuel N. Eisenstadt, the author argues that various modernisation processes have taken place in different societies, so multiple modernities have come to be, only some of which have negatively impacted religiosity. These conclusions are not new. Davie herself has used them in several books. But at least they allow a better evaluation of the strengths and weaknesses (and one-sidedness) of the two main theories. Here, however, it is possible to ask whether there are indeed only two theories? The author herself had been claiming the very opposite in the preceding pages, so on this point she may be oversimplifying. In criticising existing approaches, she instead paves the way for the presentation of her own views, which are not universally accepted. This kind of approach must be favourably acknowledged, but the question is whether it belongs in an introductory book such as this.

The first chapter of the 'substantial' section of the book uses a number of typical expressions: Western Europeans are described as 'believing without belonging', moving from obligation to consumption, but in extreme situations pay- 
ing attention to the 'vicarious' function of various churches. All of this will be familiar to those who have already read Davie [cf. Davie 1994, 2000]. Although the author of this article feels an affinity with many of the explanations, they are not without problems, and the opinions of objectors should also be taken into account - both those who persist in the secularisation thesis (Steve Bruce) and the rational choice theorists. It is too easy to criticise American sociologists for introducing aprioristic ('economistic' and religious) attitudes to the social sciences without giving them the opportunity to defend themselves, and, further, without even obtaining a proper description of what they are really proposing. If the rational choice theorists disagree with Davie over 'vicariousness' - they understand it as the dismissal of religion, while she sees it as one of religion's late modern forms - can the author of one concept be allowed to evaluate her own attitude as superior, saying that popular religion has always functioned in terms of church vicariousness? And is not the concern for church 'vicariousness' also a kind of religious apriorism?

Fortunately, such subjectivity is rare. Davie (and the great majority of contemporary sociologists) is well aware, for example, that previous interest in the new religious movements did not correspond with their social impact, and was often influenced by political (and church) factors. Hence, in the chapter on minority religions, she rightly maintains that immigrant faith communities and the majority's attitudes towards them are substantially more important in this respect. One of the best chapters in the book is devoted to fundamentalism, understood as essentially a late modern phenomenon that arose not only on a religious basis. Eisendtadt's study of the 'Jacobine dimension of modernity' [Eisenstadt 1999] allows the author to detect fundamentalist features in the enlightened ideologies of progress and secularity, as well as in some animal rights movements, certain types of feminism, and so on. 'Religious movements are not the only ones that succumb to fundamentalist tendencies, a situation greatly exacerbated by the uncertainties of the late modern world' [Davie 2007: 199]. Here one can go back to the author's earlier statement that just as religious participation declined in Europe in the second half of the 20th century the same was true of trade unions and political parties, and thus so-called secularisation was nothing but an expression of a much wider societal (not just religious) process.

Davie adopts similarly up-to-date perspectives with respect to other topics such as globalisation and the transnational nature of religious bodies or the increasingly popular phenomena of everyday religion, which includes the recent growth in death studies, etc. From the macro-social perspective, the most important observation is that in contemporary Western Europe, churches operate by way of two different, not always compatible, modes: 'the first of these is concerned with birth and baptism ... here is the model of choice. The second relates to death and ... it reflects the persistence of vicarious religion' [Davie 2007: 242]. Davie hereby widens the observation of her close colleague, French sociologist Danièle Hervieu-Léger, who argues that 'the two sides of the coin' of modern religiosity are the converts and the pilgrims, those who became religious by choice, 
and those for whom 'spiritual seeking' is the goal, while both prefer de-traditionalised and highly individualised forms of religion [Hervieu-Léger 1999].

The Introduction to the Sociology of Religion, by the two Norwegian scholars named above, is a somewhat more normal introduction to the discipline [Furseth and Repstad 2006]. ${ }^{2}$ The authors begin with definitions of sociology and religion, whereupon they devote attention to classical and contemporary sociological theories and 'great narratives'. They then deal with the impact of religion on different institutional spheres: public space, individuality, specific organisations, ethnicity and gender. The book concludes with a chapter on the reciprocal ties between sociology, theology, and religious faith. The seemingly traditional outlook of the book is, however, just a first impression. Furseth and Repstad sometimes opt for the customary approach to presenting facts, as when they identify the discipline's 'founding fathers' (they are the same as in Davie), but sometimes they do not. They include Freud, Mead and Parsons in their list of the sociology of religion 'classics', a psychologist obsessed with fighting the churches, and two sociologists who did not devote a great deal of attention to the subject, and in their list of the 'contemporaries', to which one would assume that Berger, Luckmann and Luhmann do belong, one would probably not believe so of Habermas, Goffman, Bourdieu, Foucault, Giddens, and Baumann. This selection is examined in more detail in the next chapter, but, this author would like to point out that this is a very specific way of rejecting the Beckfordian concept of the 'insulation and isolation' of the sociology of religion.

However, the key chapter dealing with the history of the discipline is not one of the brief introductions to its main thinkers but one on its 'great narratives': modernity and post-modernity, globalisation and secularisation. While the first issue is connected more with mainstream sociology (in the same way as the aforementioned selection of key scholars) and the second is rather sketchy, the last allows Furseth and Repstad to introduce and criticise secularistic and rational choice perspectives in much the same way as Davie did. They agree with Jean-François Lyotard's post-modernist approach, that all the great narratives are dead, but here and elsewhere they express a somewhat give-and-take approach: 'different scholars provide various answers to this [and that] question ... We are unable to conclude with general validity the trend in these changes' [Furseth and Repstad 2006: 132]. Although the concept of 'sometimes-true theories' [ibid.: 142] seems clever, this author would at least sometimes prefer that the attitudes were more certain, since in all probability the only 'certain' statement the Norwegian sociologists put forward in their book is that they are more convinced about the late modern than the post-modern character of our times [ibid.: 79]. Another important point must also be made here: a wider and deeper conceptualisation of the 'obsolete great narratives' in the scientific study of religion has already been made by the American sociologist Meredith McGuire [2001: 285-299].

2 The book can be compared, for example, with the book by Christiano, Swatos and Kiwisto [2001]. 
Furseth and Repstad's Introduction is thus more of an overview of various 'sometimes true' theories and selective issues, which does not provide much new insight at either the theoretical or empirical level. Moreover, the authors are not always accurate on the empirical level: sociology has not been taught at universities since Comte's times [Furseth and Repstad 2006: 1]; Roland Robertson is not an American scholar [ibid.: 17]; the authors' description of Polish religiosity does not devote any attention to developments over the past few years [ibid.: 152]; The Fundamentals were published in America before the 1920s [ibid.: 156], and so on. Although I am reasonably sure that no overview can emerge without similar errors, hand in hand with the aforementioned problems, I feel bound to stress that this kind of work provides merely an 'academic standard', and as such it cannot much fascinate. Special issues such as theoretical breadth and the reciprocal relationship between religion and theology will be discussed below; at this point the author would like to turn the reader's attention to the recently published Czech work Sociology of Religion [Nešpor and Lužný 2007]. ${ }^{3}$

Nešpor and Lužný combine both historical and thematic perspectives. After a brief introduction dealing with the importance of religion(s) to the contemporary world, sociological approaches to the study of religion as opposed to other viewpoints, and a short description of the development of the sociology of religion, they divide their book into six main chapters in the first two of which they concentrate on classical approaches, initially in much the same way as the authors of the aforementioned books, but subsequently widened with respect to the post-Second World War period. Here, Nešpor and Lužný maintain the predominant position of Anglo-American scholars, which they term mainstream, but also dedicate a special section to French (and Belgian) and German sociologists whose work is introduced in more detail than by Davie (especially the French contribution; the authors argue that the only German theorists of any importance were Thomas Luckmann and Niklas Luhmann). A further section is subsequently devoted to the study of new religious movements, Lužný's long-time specialisation [e.g. Lužný 1997, 2000], which attempts to describe in detail the abandonment of the 'brainwashing model' of conversion and anti-cult attitudes for a more balanced scholarly understanding of these phenomena.

The authors' attempts to cover recent substantial, particularly (Western and Eastern) European and (North) American, religious issues are of particular interest. In this respect, Nešpor and Lužný introduce what they call 'alternative approaches' to the former mainstream(s) including Luckmann's famous concept of 'invisible religion' and various forms of implicit religiosity dealing with func-

3 Although Czech sociology did not neglect the topic of religion altogether and in the 1960s its empirical findings had wider international impact [Kadlecová 1972], Nešpor argues elsewhere that its theoretical side has been weak [Nešpor 2007b]. The last general book on the sociology of religion was published during communism in the 1980s, heavily influenced by the anti-religious 'scientific-atheistic' attitudes of those times [Sekot 1985], with only a very few others preceding it. 
tional surrogates of established religion, American civil religion, and other forms of substitutes for religion, in all cases widely underpinned by both historical and contemporary examples. The history of political, implicit religions, for example, is not limited to the tragic 20th-century ideologies of Fascism, Nazism and communism but extends back to the Enlightenment period, and the authors emphasise the striking resemblances between the anti-religiosity (anti-church movement) of the French Revolution and that of communism. In the case of more substantial forms of religiosity and other established religious bodies which are church-related, the two Czech authors deal with theories of religious de-privatisation, ethnic religion, and de-secularisation (demonstrated using certain Muslim societies), the religious impact on politics and the rejection of religion (in Western Europe).

Although Nešpor and Lužný are trying to deal not only with Western theories and (especially) examples, in the concluding chapter they - as does Davie - mention the ethnocentrism of the sociology of religion as being one of its most serious weaknesses. Their solution to the problem, however, is questionable, as pointed out for the first time in a review by Váně [2007: 308]. The authors affirm Beck's, Giddens' and Bauman's writings on 'second' or 'reflexive' modernity, which, they assert, may almost automatically lead to the deconstruction of the 'learned conventions of everyday life, inherited mental stereotypes and laboured opinions' [Nešpor and Lužný 2007: 179], to more of an idealistic picture than a true depiction of reality. This part of the book thus seems somewhat like a propaganda speech in support of the theories favoured by the authors, in much the same way that the Norwegian authors Furseth and Repstad seem to back up mostly the same contemporary scholars, the ones that they prefer. An unbiased scientific approach only emerges in the last chapter of Nešpor and Lužnýs book, which is devoted to the 'sociology of religion from the bottom'.

The authors describe how sociologists acquire their knowledge, that is, the various research methods they use (survey, qualitative, and historic-sociological approaches), with special reference to recent domestic and comparative research performed in the Czech Republic. Subsequently, they devote an extensive annotated bibliography to issues with which they dealt only briefly (if at all) in their book. This chapter, therefore, would appear to be of significant importance for students and is written clearly in the hope of establishing a wide basis for the future development of the discipline in the post-communist Czech context. This chapter has a parallel in the sixth chapter of Davie's Sociology of Religion, which also deals with methodological issues (there is no such chapter in Furseth and Repstad). However, in the Czech case the material is more solid and impartial, and the annotated bibliography (which Davie does not have) is particularly useful, since it familiarises the reader with many issues once essential but currently less important or less attractive to the authors. Naturally, any selection of 'substantive issues' is subjective and depends on the assumptions the authors make about their readers, so such an 'invitation for further reading' might well balance the book's imperfections and possible one-sidedness. 


\section{A European sociology of religion or national sociologies of religion?}

Having briefly introduced the books under review, it is necessary to turn to the issue of author embeddedness. The most fundamental difference between the various approaches to the sociology of religion in the second half of the 20th century can be described in terms of North American scholars versus their European counterparts. This divergence is explained by the diverse roles that religion plays in these societies [e.g. Hunt 2005: 28-58]. As Steve Bruce puts it, 'from the Middle Ages to the end of the twentieth century, religion in Europe (and its offshoot settler societies) has declined in power, prestige, and popularity' [Bruce 1999: 7-8]. European sociologists were thus obsessed with elaborating (various versions of) the secularisation thesis and assumed the eventual decline of religion elsewhere. The same was true even of scholars within their own religious backgrounds such as the French Catholic sociologist Gabriel Le Bras (1955-1956) or the Anglican David Martin (1978) - some of whom tried to reverse the process.

Yet the United States has clearly been an exception in this respect. Standard versions of the theory that as modernisation processes develop the public presence and impact of religion decline automatically do not fit [cf., e.g., Lipset 1996]. If Robert N. Bellah's theory of civil religion applies anywhere, then it has to be the US (and possibly Japan), the very country in which the theory was first elaborated [Bellah 1967]. Those American sociologists who were not too influenced by functionalism eventually leaned towards the 'new paradigm' in the sociology of religion, Rodney Stark's rational choice theory, and other versions of 'religious economy' models (for an overview see Young [1996]). But is it accurate to say that only two paradigms have emerged in the discipline?

All the respective authors, along with Meredith McGuire and others, believe not. Grace Davie in particular devotes a great deal of attention to the 'national backgrounds' of various European sociologies of religion. She attempts to explain different varieties of 'Europeanness' in a manner similar to the European-American divide by taking the societal context into account. Davie ties what she calls the European assumption solely to the French sociologie religieuse, which seems something of an oversimplification, and then goes on to describe 'hybrid cases' of British, Canadian, German, and Eastern European (communist) versions of sociology of religion [Davie 2007: 33-40]. From here we can go further and also investigate the path dependencies of the respective authors, who to at least some extent represent three such 'national schools' - English, Scandinavian and post-communist.

Few would doubt that there are similarities between English-speaking scholars on the two sides of the Atlantic. British scholars 'draw considerably on American ... literature, but they operate necessarily in a European context - i.e. one of low levels of religious activity', says Davie [2007: 36], and this, mutatis mutandis, would also be true of the English-speaking Canadians [O'Toole 1984: 226-232; 1996]. Both American and English sociologists have interpreted secularisation (or 
its deceleration or even absence) in connection with the pluralisation of symbolic universes and religious groups, particularly with respect to the emergence of new religious movements. Whilst the founder of modern British sociology of religion Bryan Wilson stressed their anti-modern, gemeinschaftlich character [Wilson 1961, 1982], his American colleagues eventually lost the conviction that broadening the religious spectrum leads to secularisation (as argued by Berger [1967]) and explained structural changes in American religiosity as being caused by the emergence of new attitudes and groups [Eck 2001; Wuthnow 1998, 2005].

Generally speaking, English sociologists understood the spread of new religious movements after the 1960s as a supporting argument for the secularisation thesis, with Americans seeing it as invalidating the thesis, finally leading to the rational choice theorists' belief in the operation of a free religious market that increases the level of religiosity [Stark and Bainbridge 1985, 1987; Stark and Finke 2000]. The former group of scholars emphasised the decreasing societal impact of the state church (the Church of England in this case), and the latter the lack of established religious authority directly connected to the state and the denominational character of the American religious scene, first described by $\mathrm{H}$. Richard Niebuhr [1929]. However, both schools were somehow obsessed with new religious movements.

A deeper study of this phenomenon [Barker 1984] and the American controversy over the anti-cult movement [Zablocki and Robbins 2001] led to the abandonment of this somewhat narrow focus, directing the attention of British scholars, such as Davie herself, to the study of 'believing without belonging' and the 'vicarious function' of churches [Davie 1994, 2000], Paul Heelas and Linda Woodhead to what they recently call the holistic milieu [2005; Heelas 1996], and Robin Gill to the historical sociology of church building and attendance [Gill 2003]. In contrast, many American sociologists still emphasise the putative fundamental difference between European state churches and the American free religious market, although the former are not what they used to be (if they hold any status at all), and the latter is far from laisser faire.

State churches still exist in Europe, particularly in Scandinavia, and hence the situation there can be compared with Britain (the Church of England). In both cases, however, there is no religious oppression, and there is a high degree of freedom of faith (which cannot be said of Greece, the only other European country with a state church). The main difference between the two models, simply put, is that whilst the British prefer 'believing without belonging', the Scandinavians have the reverse, 'belonging without believing' [Davie 2007: 138-140]. Indeed, a corresponding similarity/dissimilarity can be detected in their respective religious studies, partly influenced by the spread of English amongst Nordic academics. Scandinavian scholars, especially psychologists of religion, historically devoted a great deal of attention to 'sects and cults' [e.g. Sundén 1966; Holm 2002], whereas more recently it has been possible to detect a conversion to multireligious dialogue [e.g. Grung and Larsen 2000]. 
Considering that religious studies are taught at theological faculties in Scandinavia, among the authors discussed in this study the Norwegian scholars are unique in dealing extensively with the reciprocal ties between religious faith and the sociological study thereof, expressing a 'middle ground' approach and suggesting that 'the ability to create space for critique and reflexivity ... seems to be a precondition for a combination of sociological interpretations and religious faith' [Furseth and Repstad 2006: 208]. They also attempt to establish the broadest possible theoretical background for the sociology of religion by including theorists who are not obviously regarded as proponents. In other words, scholars of (at least formal) theological origin are attempting to broaden their horizons using sociology as a whole rather than solely the sociology of religion. Indeed, Scandinavian sociologists of religion are very close to the Anglo-American tradition and form a 'hybrid case' between the American and Continental traditions, although Davie does not identify them as such. ${ }^{4}$

Another hybrid case, this time in accordance with the views of the British scholar, can be found in Germany, or rather in that (small) part of German sociological theory that deals with religion. Although most German scholars of religion used to be seen simply as advocates of the secularisation thesis, without any theoretical significance, and were heavily criticised by Thomas Luckmann [1963], Niklas Luhmann put forward a specific (and complex) functionalist theory that was primarily a counterpart to Parsons theory [Luhmann 1977]. He later emphasised the communicative role of religion as an 'autopoietic' system [Luhmann 2000]. Laermans and Verschraegen [2001] express the hope that this theory, which differs significantly from the Anglo-American mainstream and the French and Italian versions of the discipline, offers a great opportunity for the future study of the sociology of religion. However, other observers might point out that the majority of German scholars pay no special attention to religion and deal with it only within the framework of post-modern theories of societal change [Mendieta 2005], in much the same way as mainstream French sociologists like Pierre Bourdieu do [Jenkins 2002; Swartz 1997; cf. Hunt 2005: 28-43].

Turning to French and Belgian sociology of religion, it is important to bear two important factors in mind. First, as discussed above, it should not be assumed that the French tradition is the model for 'Continental religious sociology', an assumption Davie makes. French and to a lesser degree all francophone religious studies differ sharply from what is found in other European countries, ${ }^{5}$ the reason being that France was the first (and for a long time the only) country to establish a republican laïcité against its former Catholic tradition. In fact, this form of church/state separation often inverted the position of the privileged state church(es) to the dominance of an anti-church attitude [Rémond 1976; Poulat

4 The author believes that this statement is valid on the whole for Scandinavian academia, not just for Furseth, who spent several years at an American university (UCSB).

${ }^{5}$ Italy and Italian sociology of religion would be the closest case to the French and Francophone, but there is no room to deal with it extensively here. 
1987]. The second point is closely related to the first: French sociology with respect to religion is split sharply into two groups. Specialists on religion were usually connected with Catholicism and formed an exclusive Groupe de Sociologie Religieuse, while few mainstream sociologists were interested in religion at all. Taking mainstream sociologists into account first, we can follow Furseth and Repstad in their struggle for 'a demonstration of how their general perspectives can be used in the analysis of religion' [Furseth and Repstad 2006: 49], bearing in mind, however, that the attention Bataille, Baudrillard, Bourdieu, Dubet, Foucault, Tourain, and others devoted to the subject was only occasional and marginal and usually only as part of the 'grand' sociological theories of post/modernity.

The sole concern for a very specific group of French Catholic sociologists and their eventual shift from 'religious sociology' to the 'sociology of religion', 'from a group primarily motivated by religion to one motivated by science' [Davie 2007: 36] is more standard among religious scholars. As this process has already been extensively addressed [Willaime 1999; Nešpor and Lužný 2007: 88-94], it suffices to add just a few remarks here. The founding father of sociologie religieuse, Gabriel Le Bras was a canonist who had a personal interest in church history and who had close connections with the leading French historical school of the Annales, exponents of which were involved in attempting to establish more empirical historical methodology. His religious sociology was both historically oriented, with a particular reference to the embeddedness of religious institutions and behaviour, and empirically grounded in a detailed analysis of popular religious behaviour [Le Bras 1955-56]; his mapping of the Catholic pratique religieuse in the regions of France was eventually completed by Boulard and Rémy [1968]. Nonetheless, Le Bras and his colleagues were generally convinced that urbanisation in particular leads to a loss of religious faith making them followers of the secularisation thesis of a kind, even if Le Bras tried to use his sociological knowledge to reverse the process.

It was not too difficult to use Le Bras' method to map forms of popular religiosity other than Catholic [Willaime 1999: 348-352], and subsequently, members of this group also looked at the structural similarities between religion and (other) totalitarian ideologies, especially Marxism [e.g. Desroche 1955, 1962], or they studied the ideological conditioning of modernisation itself [Houtart and Rousseau 1972]. This led to the déconfessionalisation of their studies, signalled by the change of the group's name to Groupe de Sociologie des Religions et Laïcité, which gave rise to the extensive study of the interplay of religion with secular/ anti-religious culture [Poulat 1987; Willaime 1998] and the theoretical construction of religion as a 'chain of memory' [Hervieu-Léger 1993]. French sociologists began to study new religious movements within this framework [Hervieu-Léger 2001], which would seem to emphasise their own 'path dependency', instead of a one-way reception of the Anglo-Saxon models.

Other approaches to the sociological study of religion were to be found in various countries of Eastern Europe under the communist regimes. From the 
'scientific-atheistic' viewpoint, religion was rejected as 'false consciousness' and the 'opium of mankind'. However, ideologists studied the subject in order to be more able to 'support' its ultimate demise [Throwen 1983], especially in the Soviet Union, and slightly later in Czechoslovakia. It is perhaps not surprising that these old studies on the decline of religion still excite Western secularists [Bruce 2002: xii-xv]. But this is not the whole story. Another tradition in the sociological study of religion, and one significantly closer to the French tradition, emerged for example in prevailingly Catholic Poland [Majka 1967]. Eastern European sociology of religion cannot be regarded as uniform, even though secularism and the empirical study of secularisation processes on the whole did indeed prevail in the USSR, Czechoslovakia, East Germany, Hungary, and Poland.

After the revolutions of 1989, when the 'scientific-atheistic' approach was thrown aside part and parcel with the 'bright future' of communism, the range of theories and attitudes widened considerably, with only a certain number that fully accepted the Anglo-American methods of studying religion. If we take Nešpor and Lužný as an example, they lie close to the mainstream of contemporary sociology of religion, but at the same time they emphasise, for example, ideologies operating as surrogates of religion and other forms of 'invisible' religiosity, and they devote extra attention to the various trajectories of religious change in respective countries. Broadly speaking, whilst Davie applies an approach 'from above', following Eisenstadt (and Martin in his general theory of secularisation) in talking about multiple modernities, Nešpor and Lužný do the same 'from the bottom', employing their particular historical knowledge in a manner similar to that of the French sociologists and concerned principally with a given country's specific characteristics. For that matter, the position of religion in the French and Czech contexts is, in certain respects, similar, a view Z. R. Nešpor has presented elsewhere [Nešpor 2007a].

To sum up, although one cannot fully agree with the views Grace Davie presents in her brief descriptions of different national sociologies of religion, she did put forward two crucial ideas. First, it is not enough to speak of one unique sociology of religion, or even of two, say, a European and an American tradition, as is the custom [see, e.g., Warner 1993], because there are many 'smaller' but no less important variants of the discipline. Second, the differences between these 'national versions' are greatly influenced by the general situation of religion in the respective countries. This is also true of the three books with which we are concerned in this article. This being the case, Nešpor and Lužný's (and Davie's) fear of ethnocentrism in the sociology of religion seems very real and will be impossible to overcome until non-European and non-American versions of the discipline emerge and the international academic community, still dominated by the Anglo-Americans, allows 'others' to fully participate. However, this is not likely to happen soon. 


\section{The theory of and theories for the sociology of religion}

One of the reasons for the isolation of the sociology of religion from mainstream sociology has been its relative lack of 'grand' theories, since the sociology of religion has worked mainly with what Philip Benedict calls 'mid-range generalisations' [Lehmann and Ouédraogo 2003: 255]. The only major theory to emerge was the aforementioned secularisation thesis, but, as Rodney Stark puts it, this was rather one of the 'systems of thought that could accommodate all possible observations explained nothing because ahead of time they were of no predictive use - they were merely post hoc classification schemes capable only of description or codification' [Young 1996: 4]. Thus Stark with his colleagues William Sims Bainbridge, Roger Finke, Charles Y. Glock, Laurence Iannaconne, and others began to 'bring theory back in', in the form of rational choice theory [see Stark and Bainbridge 1985, 1987]. However, it is doubtful how successful they have been, especially amongst European scholars. For example, Steve Bruce devoted his one book to a criticism of rational choice theory [Bruce 1999], and others are no more enthusiastic, including the authors of the books discussed here. Davie writes, for example, that 'it is not that the market isn't there ... it is simply that the market doesn't work given the prevailing attitudes of large numbers of the population' [Davie 2007: 87], whilst Gorski argues that supply-side arguments cannot explain the historical features of religion [Gorski 2000]. So, what kind of theory or theories are Davie, Furseth and Repstad, and Nešpor and Lužný advancing?

As mentioned above, Furseth and Repstad are closer to general sociological thought. They expect, in much the same way as Deal and Beal [2004], that the inclusion of mainstream theorists, such as Bauman, Bourdieu, Foucault, Giddens, Goffman, and Habermas, would both enrich the discipline itself and fill the gap between it and mainstream social theory. However, the author is not so convinced. Social theory itself is able to exist without direct input (or, indeed, any input) from the sociology of religion, which is evident in the case of Giddens, and the sociology of religion would be unlikely to profit much from relatively old 'grand' theories. The ideal approach would thus appear to be somewhat problematic for anyone who is familiar with the history of the development of the sociology of religion. The views of Davie and of Nešpor and Lužný seem here to be more appropriate, calling for new ideas and methods in the study of what Davie calls 'ethnographic' and Nešpor [2004a] 'humanistic' approaches to religious phenomena. What do they mean by such terms?

The sociology of religion must go beyond the 'old' paradigms, the secularisation thesis, rational choice theory, and ethnocentrism. It must be multiparadigmatic and multidimensional and include the 'less developed' narratives (McGuire) of globalisation and religious trans-nationalism [see, e.g., Levitt 2007], implicit religion and surrogates of religion [e.g. Chidester 2005], as well as issues dealing with religious traditions, literacy, and popular religiosity [e.g. Lyon 2000; Prothero 2007]. The only way in which to do so is to make wider use of qualitative methods, as done recently by Nancy T. Ammerman and her colleagues [Ammer- 
man 2007], combined with classical quantitative approaches. Relevant mid-range theories can be elaborated only 'from the bottom', involving all the 'buffonia' of social facts, as Peter L. Berger once termed it. Above all, theorists must never forget that their theories concern living people and 'the ways in which nonexperts experience religion. Everyday religion may happen in both private and public life, among both privileged and nonprivileged people. It may have to do with mundane routines, but it may also have to do with the crises and special events that punctuate those routines' [ibid.: 5].

Concerning the multiple modernity approach, Davie goes as far as to say that 'post-communist Europe has become a veritable laboratory in this respect' [Davie 2007: 129]. The two Czech authors, as they are from the region in question, dare not express the same hope, but they do feel that the study of religion in these formely anti-religious countries is still largely underdeveloped. The 'religious ethnography' of Central and Eastern Europe thus seems to present a major challenge for contemporary sociology of religion which will involve revisiting many of the discipline's tried and tested theoretical and methodological tools [see also Hann 2006]. If Davie identifies 'believing without belonging' and 'vicarious religion' in the West, for example, would it not apply to the countries of the former Eastern bloc? In which countries would it apply and in which not? And why? Similarly, if both organised religiosity and anti-church attitudes are in decline in Western Europe [Willaime 1996], what is the situation in those post-communist countries that are experiencing a degree of de-secularisation? And so on and so forth. To put it simply, the sociology of religion need not worry itself so much with Stark's lack of 'grand' theory; it must rather concentrate on more accurate field research which includes all forms of visible and 'invisible' religion.

At this point it would be pertinent to return briefly to the grand issues facing the study of contemporary religion(s). Of the authors highlighted in this study, these issues are best identified by Grace Davie: mainstream and minority religions, fundamentalism, globalisation, and everyday religion [Davie 2007: 133-244]. Established churches have recently been somewhat neglected due to the 'fashionable topic' of new religious movements. Many sociologists have simply ignored the fact that established churches have changed significantly during the late modern period, and that they constitute an important element of modern religion. Therefore, we have to return to the study of mainstream religion in various parts of the world, of which merely European-American differences have been studied to date. Further, the religious margins are not made up simply of new religious movements, for which the issue of social acceptance is of major importance, but also encompasses immigrant religiosities and the problems of co-existence with the majority pluralistic 'civil religion' (in the United States) and post-Christian religious liberalism and laïcité (in Europe). Muslim and other immigrant communities are often excluded on a religious basis (or religious pretence) even though they are largely, albeit silently, experiencing the very same changes as the majority population in Western societies [Göle 2006; Roy 2006]. 
Clearly, this does not mean that immigrants (as well as the majorities) are exclusively liberal, far from it, indeed, fundamentalism, not only religious, can be seen as a direct consequence of late modernity.

The issue of fundamentalism naturally leads us to look at the impacts of globalisation on religion. As the theorist Roland Robertson puts it, globalisation means the 'compression of the world and the intensification of the consciousness of the world as a whole' [Robertson 1992: 8] leading both to the particularisation of the universal and the universalisation of the particular. Globalisation thus strengthens the quest for a particular identity, because when 'the world as a whole' is more and more experienced as a 'single place', particular groups are forced to declare their diversity and to establish their place in the global order. In such conditions, the relevance of community, 'strong' values, and a range of 'fundaments' is reinforced, while David Lehmann adds that religion can also be seen as the 'original globaliser', competing with individual countries and other political entities established in the early modern period and in the 19th and 20th centuries [Lehmann 2002]. 'God needs no passport', says Peggy Levitt [2007], and other versions of multiple modernities cited elsewhere, both 'domestic' and 'imported', are converging and strengthening both pluralistic and fundamentalist attitudes.

Last but not least Davie mentions the issue of everyday religion, a topic somewhat neglected by sociologists until very recently. However, this is a principal issue and it cannot be 'explained away' by applying the grand theories of religious change, as it has been over a long period of time with regard to modernisation, out-of-church movements, gender and life-cycle issues, social stratification in religion, and so on. These very issues must be taken seriously without applying assumptions that are usually grounded in modern (Western) 'common sense', so 'we cannot assert that religion affects the totality of human behaviour, creating believers of various strange ideas, "unbalanced" people and those committing "wrong actions", as well as those whom religion simply misuses. However, the opposite attitude would be similarly mistaken, i.e. a full ignorance of religion, since religion still constitutes the value and normative backgrounds for the great majority of mankind' [Nešpor and Lužný 2007: 11]. In other words, we should devote serious scientific attention to 'give religion(s) what is religious'. As the American sociologist Mark Juergensmeyer notes with respect to widespread religious (and antireligious) violence, 'the cure for religious violence may ultimately lie in a renewed appreciation of religion itself' [Juergensmeyer 2003: 249].

\section{Conclusion}

Whilst sociological theory and international surveys cross borders and constitute a world-wide academic community, it is evident that this is not true of the sociology of religion(s). In addition to the Anglo-American (or rather American-English) mainstream, there are important 'national' schools which employ their own 
methods and theoretical frames of reference and devote attention to particular issues connected with the situation of religion in their respective countries. We must accept the existence of multiple modernities, some of which have subdued religion and some just the opposite. Just as various religiosities often cannot be reduced to a common basis, so scholars cannot use 'one and only' theories and methods for understanding and explaining the various issues involved. The acceptance of 'national schools' in the sociology of religion thus allows us both to apply their particular approaches and to overcome their potential one-sidedness by mutual comparison, hence both widening and deepening our knowledge.

With respect to such peculiarities, we see that the specific situation of religion(s) and the study thereof in post-communist Central and Eastern Europe owes a great deal to the anti-religious legacy of previous political regimes. Such societies cannot be studied using only the tools developed in the Western sociological context, all of them are path dependent, but they must be considered as special individual cases with respect to a comparison to Western Europe. If the ideology and knowledge regime of secularism occurred anywhere, it was in Central and Eastern Europe; ${ }^{6}$ however, even here there were certain counter-flows and strong, though silent opposition. At the same time, Central and Eastern European societies have highlighted the inadequacy of the secularisation perspective of religion; the enforced decline in church attendance and other forms of organised religion did not mean the disappearance of religiosity as such. Sometimes it took the shape of implicit religious forms, including 'faith' in communism itself or the nationalistic clashes that occurred in certain countries after the fall of communism, sometimes organised religion was abandoned for more personal, subjective and de-traditionalised spirituality.

Grace Davie is thus right to ask whether 'the debates of the English-speaking world, dominated for the most part by American sociology, furnish the best resources to understand the complex evolutions of religion in the post-communist world' [Davie 2007: 39-40]? The American (or Western in general) approach does not provide the best solution, just as the secularisation thesis failed to do so in the past. Post-communist societies should not be seen as a 'religious sociologist's laboratory' only in terms of their totalitarian pasts; these very same societies have undergone many changes in terms of religion(s) since the fall of communism.

\footnotetext{
${ }^{6}$ However, this cannot be explained only by the communist legacy. Especially in the case of the Czech lands, anti-clerical modernism had much earlier roots and it was only strengthened by the communist rule [Nešpor 2004b: 283-284]. Although elaborating a sophisticated version of the secularisation thesis, Martin [1978] also paid great attention to the historical backgrounds of respective societies' development, and nowadays he states that 'instead of regarding secularization as a once-for-all unilateral process, one may rather think in terms of successive Christianizations followed or accompanied by recoils. Each Christianization is a salient of faith driven into the secular from a different angle, each pays a characteristic cost which affects the character of the recoil, and each undergoes a partial collapse into some version of "nature"" [Martin 2005: 3].
} 
Various versions of the de-secularisation of somehow 'over-secularised' societies are evident, as are the de-privatisation of established religious traditions and an influx of new religious movements and Pentecostal movements, making the issue of religion (or its denial) certainly no less interesting than in other parts of the world. The (re)establishment of old and new religions and spiritualities in this particular region demand special attention requiring ethnographic, qualitative approaches as new qualities and attitudes held by religious people (rather than simply increased numbers) emerge in Central and Eastern Europe.

ZDENĚK R. NEŠPOR is a sociologist and historian, a senior researcher at the Institute of Sociology of the Academy of Sciences of the Czech Republic, and an assistant professor at the Faculty of Humanities, Charles University. He specialises in the history and sociology of religion, economic sociology and social anthropology. He has published a hundred scientific papers, both in the Czech Republic and abroad, and seven monographs, most recently on modern Czech religion (Náboženství na prahu nové doby (Religion on the Threshold of the Modern Age) 2006) and social consequences of Czech folk music from the 1980s to the 1980s (Děkuji za bolest... (Thanks for the Pain...) 2006). Nešpor is also a co-author of one of the reviewed works - Sociology of Religion written with Dušan Lužný (2007).

\section{Reviewed works}

Davie, Grace. 2007. The Sociology of Religion. Los Angeles - London: Sage.

Furseth, Inger and Pål Repstad. 2006. An Introduction to the Sociology of Religion. Classical and Contemporary Perspectives. Aldershot: Ashgate.

Nešpor, Zdeněk and Dušan Lužný. 2007. Sociologie náboženství. (Sociology of Religion) Prague: Portál.

\section{References}

Ammerman, Nancy T. (ed.). 2007. Everyday Religion. Observing Modern Religious Lives. Oxford - New York: Oxford University Press.

Barker, Eileen V. 1984. The Making of a Moonie. Brainwashing or Choice? Oxford: Blackwell.

Beck, Ulrich, Anthony Giddens and Scott Lash (eds.). 1994. Reflexive Modernization. Politics, Tradition and Aesthetics in the Modern Social Order. Cambridge: Polity Press.

Beckford, James A. 1989. Religion and Advanced Industrial Society. London: Routledge.

Beckford, James A. 1994. 'Final Reflections.' Pp. 160-167 in Religion in Contemporary Europe, edited by J. Fulton and Peter Gee. Lewiston: E. Mellen.

Beckford, James A. 2003. Social Theory and Religion. Cambridge: Cambridge University Press.

Bellah, Robert N. 1967. 'Civil Religion in America.' Daedalus, Journal of the American Academy of Arts and Science 96: 1-21. 
Berger, Peter L. 1967. The Sacred Canopy. Elements of a Sociological Theory of Religion. New York: Doubleday.

Berger, Peter L. (ed.). 1999. The Desecularization of the World. Resurgent Religion and World Politics. Washington - Grand Rapids: EPPC + Eerdmans.

Bowie, Fiona. 2000. The Anthropology of Religion. Malden - Oxford: Blackwell.

Boulard, Fernand and Jean Rémy. 1968. Pratique religieuse urbaine et régions culturelles. Paris: Éd. Ouvrières.

Bruce, Steve. 1999. Choice and Religion. A Critique of Rational Choice Theory. Oxford - New York: Oxford University Press.

Bruce, Steve. 2002. God Is Dead. Secularization in the West. Oxford: B. Blackwell.

Byrnes, Timothy A. 2006. 'Transnational Religion and Europeanization.' Pp. 283-305 in Religion in an Expanding Europe, edited by Timothy A. Byrnes and Peter J. Katzenstein. Cambridge: Cambridge University Press.

Casanova, José. 2004. 'Der Ort der Religion im säkularen Europa.' Transit, Europäische Revue 27: 86-106.

Chidester, David. 2005. Authentic Fakes. Religion and American Popular Culture. Berkeley: University of California Press.

Chistiano, Kevin J., William H. Swatos and Peter Kivisto. 2001. Sociology of Religion. Contemporary Development. Walnut Creek: AltaMira Press.

Cipriani, Roberto. 2000. Sociology of Religion. An Historical Introduction. New York: De Gruyter.

Davie, Grace. 1994. Religion in Britain since 1945. Believing without Belonging. Oxford: B. Blackwell.

Davie, Grace. 2000. Religion in Modern Europe. A Memory Mutates. Oxford: Oxford University Press.

Davie, Grace. 2002. Europe: The Exceptional Case. Parameters of Faith in the Modern World. Darton: Longman - Todd.

Deal, William E. and Timothy K. Beal. 2004. Theory for Religious Studies. New York - London: Routledge.

Desroche, Henri. 1955. Les Shakers américains. D'un néo-christianisme à un pré-socialisme. Paris: Éd. de Minuit.

Desroche, Henri. 1962. Marxisme et religions. Paris: PUF.

Eck, Diana L. 2001. A New Religious America. How a 'Christian Country' Has Become the World's Most Religiously Diverse Nation. San Francisco: Harper.

Eisenstadt, Shmuel N. 1999. Fundamentalism, Sectarianism, and Revolution. The Jacobin Dimension of Modernity. Cambridge: Cambridge University Press.

Giddens, Anthony. 1991. Modernity and Self Identity. Self and Society in the Late Modern Age. Cambridge: Polity Press

Gill, Robin. 2003. The 'Empty' Church Revisited. Avebury: Ashgate.

Göle, Nilüfer. 2006. 'Islam, European Public Space and Civility.' Pp. 122-130 in Conditions of European Solidarity II. Religion in the New Europe, edited by Krzysztof Michalski. Budapest - New York: Central European University Press.

Gorski, Philip S. 2000. 'Historicizing the Secularization Debate. Church, State, and Society in Late Medieval and Early Modern Europe, ca. 1300 to 1700.' American Sociological Review 65: 138-167.

Grung, Anne Hege and Lena Larsen. 2000. Dialog med og uten slør. (Dialogue with and without the Veil) Oslo: Pax Vorlag.

Hann, Chris (ed.). 2006. The Postsocialist Religious Question. Faith and Power in Central Asia and East-Central Europe. Monster: Lit.

Hardgrove, Barbara. 1989. The Sociology of Religion. Classical and Contemporary Approaches. Arlington Heights: H. Davidson. 
Heelas, Paul. 1996. The New Age Movements. The Celebration of the Self and the Sacralization of Modernity. Oxford: Blackwell.

Heelas, Paul and Linda Woodhead (with Benjamin Seel, Bronislaw Szerszynski and Karin Tusting). 2005. The Spiritual Revolution. Why Religion Is Giving Way to Spirituality. Oxford: Blackwell.

Hervieu-Léger, Danièle. 1993. La Réligion pour mémoire. Paris: CERF.

Hervieu-Léger, Danièle. 1999. Le Pélerin et le converti. La Religion en mouvement. Paris: Flammarion.

Hervieu-Léger, Danièle. 2001. La religion en miettes, ou la question des sectes. Paris: Calmann-Lévy.

Niebuhr, H. Richard. 1929. The Social Sources of Denominationalism. New York: H. Holt.

Holm, Nils G. 2002. Religionspsykologins Grunder. (Essentials of the Psychology of Religion) Åbo: Åbo Akademi.

Houtart, Francçois and André Rousseau. 1972. The Church and Revolution. From the French Revolution of 1789 to the Paris Riots of 1968, from Cuba to Southern Africa, from Vietnam to Latin America. Maryknoll: Orbis Books.

Hunt, Stephen. 2005. Religion and Everyday Life. London - New York: Routledge.

Jenkins, Richard. 2002. Pierre Bourdieu. A Critical Introduction. London - New York: Routledge.

Johnstone, Ronald L. 2004. Religion in Society. A Sociology of Religion. Upper Saddle River: Pearson.

Juergensmeyer, Mark. 2003. Terror in the Mind of God. The Global Rise of Religious Violence. Berkeley: University of California Press.

Kadlecová, Erika. 1972. 'Czechoslovakia.' Pp. 117-134 in Western Religion. A Country by Country Sociological Inquiry, edited by Hans Mol. Hague - Paris: Mouton.

Laermans, Rudi and Gert Verschraegen. 2001. "“The Late Niklas Luhmann” on Religion. An Overview.' Social Compass 48 (1): 7-20.

Le Bras, Gabriel. 1955-56. Études de sociologie religieuse I-II. Paris: PUF.

Lehmann, David. 2002. 'Religion and the Globalization.' Pp. 299-315 in Religions in the Modern World. Traditions and Transformations, edited by Linda Woodhead (in association with Paul Fletcher, Hiroko Kawanami and David Smith). London: Routledge.

Lehmann, Hartmut and Jean Martin Ouédraogo (eds.). 2003. Max Webers Religionssoziologie in interkultureller Perspektive. Göttingen: Vandenhoeck \& Ruprecht.

Levitt, Peggy. 2007. God Needs No Passport. Immigrants and the Changing American Religious Landscape. New York - London: New Press.

Lipset, Seymour M. 1996. Amarican Exceptionalism. New York: W. W. Norton.

Luckmann, Thomas. 1963. Das Problem der Religion in der modernen Gesellschaft. Freiburg: Rombach.

Luhmann, Niklas. 1977. Funktion der Religion. Frankfurt am Main: Suhrkamp.

Luhmann, Niklas. 2000. Die Religion der Gesellschaft. Frankfurt am Main: Suhrkamp.

Lužný, Dušan. 1997. Nová náboženská hnutí. (New Religious Movements) Brno: MU.

Lužný, Dušan. 2000. Zelení bódhisattvové. Sociálně a ekologicky angažovaný buddhismus. (Green Bodhisattvas. Socially and Ecologically Engaged Buddhism) Brno: MU.

Lyon, David. 2000. Jesus in Disneyland. Religion in Postmodern Times. Cambridge: Polity Press.

Majka, Józef. 1967. 'The Sociology of Religion in Poland.' Pp. 227-247 in The Valley of Silence. Catholic Thought in Contemporary Poland, edited by James J. Zatko. London: University of Notre Dame Press.

Martin, David. 1978. A General Theory of Secularization. Oxford: Blackwell. 
Martin, David. 2005. On Secularization. Towards a Revised Theory. Aldershot: Ashgate.

McGuire, Meredith B. 2001. Religion. The Social Context. Belmond: Wadsworth (5 $5^{\text {th }}$ ed.).

Mendieta, Eduardo (ed.). 2005. The Frankfurt School on Religion. Key Writings by the Major Thinkers. New York - London: Routledge.

Nešpor, Zdeněk R. 2004a. 'Ekonomistický redukcionismus a humanistická perspektiva v současné sociologii náboženství.' (Economic Reductionism and Humanistic Perspective in Contemporary Sociology of Religion) Religio, Revue pro religionistiku 12 (2): 163-186.

Nešpor, Zdeněk R. 2004b. 'Religious Processes in Contemporary Czech Society.' Sociologický časopis/Czech Sociological Review 40 (3): 277-295.

Nešpor, Zdeněk R. 2007a. 'Paradoxy sociálního a politického působení náboženství v "sekularizované" Evropě.' (Paradoxes of the Social and Political Impacts of Religion in 'Secularised' Europe) Sociální studia 3: 17-30.

Nešpor, Zdeněk R. 2007b. 'Česká sociologie náboženství v letech 1948-89.' (Czech Sociology of Religion in 1948-1989) Sociologický časopis/Czech Sociological Review 43 (4): 675-698.

O’Toole, Roger. 1984. Religion. Classic Sociological Approaches. Toronto: McGraw - Hill Ryerson.

O'Toole, Roger. 1996. 'Religion in Canada. Its Development and Contemporary Situation.' Social Compass 43: 119-134.

Poulat, Émile. 1987. Liberté, lä̈cité. La guerre des deux Frances et le principe de la modernité. Paris: CERF.

Prothero, Stephen. 2007. Religious Literacy. San Francisco: Harper.

Rémond, René. 1976. L'anticléricalisme en France de 1815 à nos jours. Paris: Fayard.

Robertson, Roland. 1992. Globalization. Social Theory and Global Culture. London: Transaction.

Roy, Olivier. 2006. 'Islam in Europe. Clash of Religions or Convergence of Religiosities?' Pp. 131-144 in Conditions of European Solidarity II. Religion in the New Europe, edited by Krzysztof Michalski. Budapest - New York: Central European University Press.

Sekot, Aleš. 1985. Sociologie náboženství. (Sociology of Religion) Prague: Svoboda.

Stark, Rodney and William S. Bainbridge. 1985. The Future of Religions. Secularization, Revival and Cult Formation. Berkeley: University of California Press.

Stark, Rodney and William S. Bainbridge. 1987. A Theory of Religion. New York: P. Lang.

Stark, Rodney and Roger Finke. 2000. Acts of Faith. Explaining the Human Side of Religion. Berkeley: University of California Press.

Sundén, Hjalmar. 1966. Die Religion und die Rolen. Einer Psychologische Untersuchung der Frömigkeit. Berlin: Töpelmann.

Swartz, David. 1997. Culture and Power. The Sociology of Pierre Bourdieu. Chicago: University of Chicago Press.

Throwen, James. 1983. Marxist-Leninist 'Scientific Atheism' and the Study of Religion and Atheism in the U.S.S.R. Berlin - New York: Mouton.

Váně, Jan. 2007. 'Z. Nešpor - D. Lužný: Sociologie náboženství.' Religio, Revue pro religionistiku 15 (2): 305-309.

Vidich, Arthur J. and Stanford M. Lyman. 1985. American Sociology. Worldly Rejections of Religion and Their Directions. New Haven: Yale University Press.

Warner, R. Stephen. 1993. 'Work in Progress toward a New Paradigm for the Sociological Study of Religion in the United States.' American Journal of Sociology 98 (5): 1044-1093.

Willaime, Jean-Paul. 1996. 'Laïcité et religion en France.' Pp. 153-171 in Identités religieuses en Europe, edited by Grace Davie and Danièle Hervieu-Léger. Paris: La Découverte.

Willaime, Jean-Paul. 1998. 'Religious and Secular France between Northern and Southern Europe.' Social Compass 45 (1): 155-174. 
Willaime, Jean-Paul. 1999. 'French-Language Sociology of Religion in Europe since the Second World War.' Schweizerische Zeitschrift für Soziologie 25 (2): 343-371.

Wilson, Bryan R. 1961. Sect and Society. Berkeley: University of California Press.

Wilson, Bryan R. 1982. Religion in Sociological Perspective. Oxford: Oxford University Press.

Wuthnow, Robert. 1998. After Heaven. Spirituality in America since the 1950s. Berkeley: University of California Press.

Wuthnow, Robert. 2005. America and the Challenges of Religious Diversity. Princeton - Oxford: Princeton University Press.

Young, Lawrence A. (ed.). 1996. Rational Choice Theory and Religion. Summary and Assessment. New York - London: Routledge.

Zablocki, Benjamin and Thomas Robbins (eds.). 2001. Misunderstanding Cults. Searching for Objectivity in a Controversial Field. Toronto: University of Toronto Press. 